Wojciech Zoń

Uniwersytet $w$ Biatymstoku

\title{
KOMPETENCJE WŁADZY WYKONAWCZEJ WOBEC EUROPEJSKIEGO UGRUPOWANIA WSPÓŁPRACY TERYTORIALNEJ Z PERSPEKTYWY POLSKI
}

\section{Wstęp}

W ciągu kilku ostatnich lat współpraca transgraniczna stała się rozpowszechnioną formą sąsiedzkich stosunków międzynarodowych - przede wszystkim w Unii Europejskiej ${ }^{1}$. Jest realizowana głównie przez jednostki samorządu terytorialnego i organizacje pozarządowe. Współpraca odbywa się głównie na podstawie umów i porozumień, nierzadko $\mathrm{w}$ ramach wyspecjalizowanych $\mathrm{w}$ tym zakresie podmiotów. Jednym z nich jest europejskie ugrupowanie współpracy terytorialnej (EUWT) - organizacja, która na mocy unijnych przepisów może zostać utworzona w każdym państwie członkowskim UE przez zainteresowane tym strony².

Kreowanie nowej formy współpracy transgranicznej, skupiającej głównie władze lokalne i regionalne, nie mogło obyć się bez wątpliwości natury ustrojowej, a zwłaszcza kwestii zależności takich ugrupowań od konstytucyjnej władzy wykonawczej danego państwa. Zgłębiając tematykę EUWT ${ }^{3}$, początkowo trudno było oswoić się z zaproponowaną przez Unię Europejską koncepcją relacji władzy publicznej i władz regionalnych tudzież lokalnych - zwłaszcza przy świadomości, że z polskiej perspektywy chodzi generalnie o województwa i inne formy samorządu terytorialnego.

Szerzej o współpracy transgranicznej np.: M. Perkowski (red.), Współpraca transgraniczna. Aspekty prawno-ekonomiczne, Białystok 2010; S. Dołzbłasz, A. Raczyk, Współpraca transgraniczna w Polsce po akcesji do UE, Warszawa 2010; P. Solarz, Współpraca transgraniczna jako czynnik procesu integracji europejskiej, Warszawa 2009. Rozporządzenie (WE) nr 1082/2006 Parlamentu Europejskiego i Rady z dnia 5 lipca 2006 r. w sprawie europejskiego ugrupowania współpracy terytorialnej (Dz.Urz. UE L 210 z 31.7.2006 z późn. zm.).

3 Poprzez obronę pracy dyplomowej poświęconej EUWT, publikacje naukowe i czynny udział w kilku konferencjach związanych ze współpraca transgraniczna, a także członkostwo w zespole roboczym ds. przygotowawczych związanych z uruchomieniem Europejskiego Ugrupowania Współpracy Terytorialnej „Polska Wschodnia” i Europejskiego Ugrupowania Współpracy Terytorialnej „Puszcza Białowieska” powołanych przez Marszałka Województwa Podlaskiego. 
Powstaje pytanie - jak EUWT funkcjonuje i funkcjonować będzie z perspektywy władzy wykonawczej w Polsce, a szczególnie po nowelizacji ustawy o EUWT ${ }^{4}$. By to ustalić, z jednej strony dokonana zostanie prezentacja formuły EUWT (w tym procesu zakładania takich ugrupowań), z drugiej strony czynione będą odniesienia pod kątem kompetencji polskich organów władzy wykonawczej wobec EUWT.

\section{Podstawy EUWT}

„EUWT to typ korporacyjny osoby prawnej, zbliżony do stowarzyszenia, nabywający osobowość prawną z chwilą wpisu do Rejestru Europejskich Ugrupowań Współpracy Terytorialnej"5. Założenie terytorialne ugrupowania jest bardzo bliskie koncepcji euroregionów, jednak w przeciwieństwie doń w państwie członkowskim UE, gdzie znajduje się jego siedziba, „ma zdolność prawną i zdolność do czynności prawnych o najszerszym zakresie przyznawanym osobom prawnym na mocy prawa krajowego tego państwa członkowskiego"6, co znacznie upraszcza współpracę. EUWT mogą w założeniu ułatwić interakcję społeczną i polityczną na szczeblu ponadnarodowym, zacierając granice, a także zachęcać do współpracy transgranicznej wiele podmiotów - w tym władze lokalne, regiony i państwa. Tym samym wzmocniono pozycję regionów koszem władz centralnych - nastąpiła redefinicja relacji centrum-peryferie ${ }^{7}$. Anca Adriana Cucu twierdzi, że formuła EUWT jest elementem procesu europeizacji kandydatów i obecnych członków Unii Europejskiej oraz sprzyja rozwojowi idei europejskiej przestrzeni administracyjnej ${ }^{8}$. Ta ocena wydaje się trafna. Jest to również efekt wzrostu znaczenia struktur lokalnych na arenie międzynarodowej, któremu towarzyszy większa aktywność międzynarodowa samorządów ${ }^{9}$.

EUWT działa na podstawie przepisów unijnych oraz prawa krajowego. Na poziomie całej Unii Europejskiej stosuje się Rozporządzenie (WE) nr 1082/2006 Parlamentu Europejskiego i Rady z dnia 5 lipca 2006 r. w sprawie Europejskiego

$4 \quad$ Ustawa z dnia 11 września 2015 r. o zmianie ustawy o europejskim ugrupowaniu współpracy terytorialnej (Dz.U. z 2015 r., poz. 1884).

$5 \quad$ Art. 84a. Zasady przystępowania gminy do międzynarodowych zrzeszeń społeczności lokalnych i regionalnych określają odrębne przepisy, (w:) K. Bandarzewski et al., Ustawa o samorządzie gminnym. Komentarz, LexPolonica $\mathrm{nr} 8175265$.

6 Art. 1 ust. 4. Rozporządzenia (WE) nr 1082/2006..., op. cit.

7 E. Nadalutti, Does the 'European Grouping of Territorial Co-operation'Promote Multi-level Governance within the European Union?, „Journal of Common Market Studies” 2013, Vol. 51 (4), s. 768.

8 A.A. Cucu, Enhancing the Performance of Cross Border Cooperation Governance through Legal Community Instruments: the Case of the European Group of Territorial Co, „Eurolimes” 2011, vol. 3, p. 208. Szerzej na temat europejskiej przestrzeni administracyjnej: J. Supernat, Europejska przestrzeń administracyjna (zagadnienia wybrane), (w:) Europeizacja polskiego prawa administracyjnego, Z. Janku, Z. Leoński, M. Szewczyk, M. Waligórski, K. Wojtczak (red.), Wrocław 2005, s. 78-86.

9 Por.: M. Perkowski, Międzynarodowa współpraca..., op. cit., Białystok 2013, s. 35-47; A. Skorupska, M. Wojnarowicz, Międzynarodowe sieci samorządowe jako skuteczne narzędzie wpływu, „Biuletyn PISM” 2015, vol. 34 (1271), s. 1-2. 
Ugrupowania Współpracy Terytorialnej ${ }^{10}$. Rozporządzenie nr 1082/2006 zostało częściowo zmienione i uzupełnione przez Rozporządzenie Parlamentu Europejskiego i Rady (UE) nr 1302/2013 zmieniające Rozporządzenie (WE) nr 1082/2006 Parlamentu Europejskiego i Rady z dnia 5 lipca 2006 r. w sprawie europejskiego ugrupowania współpracy terytorialnej (EUWT) w celu doprecyzowania, uproszczenia i usprawnienia procesu tworzenia takich ugrupowań oraz ich funkcjonowania $^{11}$. Ponadto należy również zwrócić uwagę na tzw. „Dyrektywę klasyczną”, czyli Dyrektywę 2004/18/WE Parlamentu Europejskiego i Rady z dnia 31 marca 2004 r. w sprawie koordynacji procedur udzielania zamówień publicznych na roboty budowlane, dostawy i usługi ${ }^{12}$, która pomaga zdefiniować pojęcie ,podmiot prawa publicznego". Jeżeli chodzi o zatrudnianie pracowników przez EUWT, to umowy mogą być zawierane albo według prawa prywatnego, albo według prawa publicznego.

W Polsce EUWT funkcjonują przede wszystkim w oparciu o aktualną Ustawę z dnia 7 listopada 2008 r. o europejskim ugrupowaniu współpracy terytorialnej ${ }^{13}$ (zwaną dalej Ustawą o EUWT). Pomocniczo stosuje się także Ustawę z dnia 7 kwietnia 1989 r. Prawo o stowarzyszeniach ${ }^{14}$.

Oprócz prawa unijnego i krajowego ustawodawstwa, ugrupowanie działa w oparciu o konwencję (nie chodzi tu o umowę międzynarodową w rozumieniu prawa traktatów czy polskiej ustawy o umowach międzynarodowych) zawartą jednogłośnie przez jego członków oraz wypracowany na jej podstawie statut ${ }^{15}$.

Zgodnie z art. 1 ust. 1 Rozporządzenia o EUWT, celem ugrupowań EUWT jest „ułatwianie i wspieranie w szczególności współpracy terytorialnej, w tym co najmniej jednego z jej komponentów: współpracy transgranicznej, transnarodowej lub międzyregionalnej, między jego członkami określonymi w art. 3, ust. 1, z myślą o wzmocnieniu spójności gospodarczej, społecznej i terytorialnej Unii" ${ }^{16}$. Należy

10 Rozporządzenie (WE) nr 1082/2006..., op. cit.

11 Rozporządzenie Parlamentu Europejskiego i Rady (UE) nr 1302/2013 zmieniającego Rozporządzenie (WE) nr 1082/2006 Parlamentu Europejskiego i Rady z dnia 5 lipca 2006 r. w sprawie europejskiego ugrupowania współpracy terytorialnej (EUWT) w celu doprecyzowania, uproszczenia i usprawnienia procesu tworzenia takich ugrupowań oraz ich funkcjonowania (Dz.Urz. UE L347/303 z 20 grudnia 2013 r.). Por.: M. Pechstein, M. Deja, Was ist und wie funktioniert ein EVTZ?, „Europarecht” 2011, vol. 46, p. 357-383.

12 Dyrektywa 2004/18/WE Parlamentu Europejskiego i Rady z dnia 31 marca 2004 r. w sprawie koordynacji procedur udzielania zamówień publicznych na roboty budowlane, dostawy i usługi (Dz.Urz. UE L 134 z 30.04.2004 r., s. 114). Polski ustawodawca wskazuje Ustawę z dnia 29 stycznia 2004 r. Prawo zamówień publicznych (Dz.U. z 2013 r. poz. 907, z późn. zm.). Por.: J. Zimmermann, Prawo administracyjne, Warszawa 2014, s. 186.

13 Dz.U. Nr 218, poz. 1390 z późn. zm.

14 Dz.U. 1989 nr 20 poz. 104 z późn. zm. Zob.: A. Piotrowska, Europejskie Ugrupowanie Współpracy Terytorialnej - nowy podmiot administrujący, „Zeszyty Naukowe Uniwersytetu Ekonomicznego w Krakowie” 2011, vol. 870, s. 198.

15 Art. 2 ust. 1. wprowadzony na mocy art. 1. Rozporządzenia Parlamentu Europejskiego i Rady (UE) nr 1302/2013..., op. cit. Por.: M. Ofiarska, Współpraca gospodarcza i finansowa j.s.t. z organami lokalnymi państw sąsiednich, (w:) Finanse samorządowe - 580 pytań i odpowiedzi: wzory uchwał, deklaracji, decyzji, umów, (red.) C. Kosikowski, J.M. Salachna, Warszawa 2012, s. 231; A. Piotrowska, Europejskie Ugrupowanie..., op. cit. s. 188.

16 Art. 1 ust. 1. Rozporządzenia (WE) nr 1082/2006..., op. cit. Por.: M. Kment, Der Europäische Verbund für territoriale Zusammenarbeit, „Die Verwaltung” 2012, vol. 45, p. 155-169. 
tu jeszcze wskazać punkt 11 owego rozporządzenia, który określa, że ugrupowanie działa „,w celu realizacji programów lub projektów współpracy terytorialnej współfinansowanych przez Wspólnotę, w szczególności w ramach funduszy strukturalnych zgodnie z rozporządzeniem (WE) nr 1083/2006 i z Rozporządzeniem (WE) nr 1080/2006 Parlamentu Europejskiego i Rady z dnia 5 lipca 2006 r. w sprawie Europejskiego Funduszu Rozwoju Regionalnego, albo w celu podejmowania działań w zakresie współpracy terytorialnej będących wyłączną inicjatywą państw członkowskich i ich władz regionalnych i lokalnych, niezależnie od tego, czy Wspólnota wnosi do nich wkład finansowy"17. Wspomniana wcześniej kwestia podmiotów, które mogą tworzyć ugrupowania, wymaga dokładniejszej analizy.

Według prawa unijnego ugrupowania mogą tworzyć:

- „państwa członkowskie lub władze na szczeblu krajowym;

- władze regionalne;

- władze lokalne;

- przedsiębiorstwa publiczne w rozumieniu art. 2 ust. 1 lit. b) dyrektywy 2004/17/WE Parlamentu Europejskiego i Rady lub podmioty prawa publicznego w rozumieniu art. 1 ust. 9 akapit drugi dyrektywy 2004/18/WE Parlamentu Europejskiego i Rady;

- przedsiębiorstwa, którym powierzono realizację usług świadczonych w ogólnym interesie gospodarczym zgodnie z krajowym oraz unijnym prawem właściwym.

- krajowe, regionalne lub lokalne władze albo podmioty lub przedsiębiorstwa publiczne równoważne $\mathrm{z}$ tymi, o których mowa w lit. d), z państw trzecich, $\mathrm{z}$ zastrzeżeniem warunków określonych $\mathrm{w}$ art. $3 \mathrm{a}{ }^{\prime 18}$.

Ponadto wskazuje się możliwość przystąpienia stowarzyszeń, w skład których wchodzą podmioty należące do jednej lub kilku z wymienionych wyżej kategorii. Istnieje również możliwość członkostwa w EUWT podmiotów z państw trzecich (spoza UE) albo krajów lub terytoriów zamorskich ${ }^{19}$.

Wydaje się, że w szerszym wymiarze założenie danego EUWT przez jego członków jest kolejnym etapem współpracy i wyrazem pogłębionego zaufania - związane jest to ze sprawdzeniem się dotychczasowej współpracy między partnerami dzięki wywiązywaniu się z porozumień partnerskich i realizacji wspólnych projektów, $\mathrm{w}$ tym w oparciu o formułę euroregionu.

17 Pkt 11. Rozporządzenia (WE) nr 1082/2006..., op. cit. Zob.: K. Varró, Spatial governance in the Dutch-GermanBelgian borderlands, „International Journal of Urban and Regional Research” 2014, vol. 38 (6), p. 2249. Art. 3 ust. 1. Rozporządzenia (WE) nr 1082/2006..., op. cit. Warto przyjrzeć się bardziej szczegółowo poję-
ciu i statusowi prawnemu władz regionalnych i lokalnych - Zob.: C. Mik, Status władz regionalnych i lokalnych państw członkowskich Unii Europejskiej w świetle prawa wspólnotowego, „Ruch Prawniczy, Ekonomiczny i Socjologiczny" 2006, vol. 68 (2), s. 222-252.

19 Ibidem, art. 3 ust. 1 oraz art. 3a. Warto wskazać, że ze względu na kategorie podmiotów należących do danego EUWT można dokonać podziału ugrupowań na jednorodzajowe oraz wielorodzajowe - zob.: A. Piotrowska, Europejskie Ugrupowanie..., op. cit., s. 195-196. 


\section{Procedura tworzenia lub likwidacji EUWT z perspektywy władzy wykonawczej w Polsce}

Decyzja o utworzeniu EUWT jest podejmowana z inicjatywy jej przyszłych członków $^{20}$. Ma ona charakter dobrowolny. Pierwszym krokiem może być podjęcie uchwały intencyjnej o rozpoczęciu prac nad utworzeniem ugrupowania. Nie jest to krok niezbędny, choć może pomóc w ustaleniu wstępnych warunków działalności przyszłego EUWT, jak chociażby uzgodnienie siedziby ugrupowania - jest to kwestia ważna, gdyż determinuje wybór prawa krajowego właściwego wobec danego EUWT.

Następnym krokiem - tym razem obligatoryjnym - jest opracowanie oraz przyjęcie konwencji i statutu danego EUWT przez przyszłych członków ${ }^{21}$. Jest to niezbędny element wniosku o wyrażenie zgody na przystąpienie do ugrupowania oraz do zgłoszenia do rejestru ugrupowania mającego siedzibę statutową w Polsce. Z tym krokiem wiąże się również podjęcie uchwały albo decyzji przez członków o przystąpieniu do danego ugrupowania, która to uchwała (w przypadku jednostek samorządu terytorialnego lub Rzeczypospolitej Polskiej) albo decyzja (w przypadku innych podmiotów prawa publicznego) również stanowi element wniosku. Uchwałę w jednostce samorządu terytorialnego podejmuje organ stanowiący tej jednostki bezwzględną większością głosów ustawowego składu ${ }^{22}$. Zgodnie z Ustawą o EUWT uchwałę o przystąpieniu Rzeczypospolitej Polskiej do EUWT podejmuje Rada Ministrów, wyznaczając ministra właściwego do reprezentowania RP w tym ugrupowaniu. Po niedawnej nowelizacji ww. ustawy określono również warunki udziału w EUWT organów administracji rządowej - w tym wypadku zgodę w drodze uchwały wyraża Rada Ministrów ${ }^{23}$. Pozostałe podmioty prawa publicznego podejmują natomiast decyzję o przystąpieniu do ugrupowania na podstawie ich przepisów wewnętrznych.

Zgoda na przystąpienie jednostki samorządu terytorialnego lub innego podmiotu prawa publicznego jest podjęta $\mathrm{w}$ drodze decyzji ministra właściwego ds. zagranicznych w uzgodnieniu z innymi ministrami - ministrem właściwym do spraw wewnętrznych, ministrem właściwym do spraw finansów publicznych oraz ministrem właściwym do spraw rozwoju regionalnego. Każdy z ministrów ma 21 dni na wyrażenie opinii, a niezajęcie stanowiska przez danego ministra oznacza uzgodnienie decyzji. Należy jednak podkreślić, że minister właściwy do spraw zagranicz-

Na potrzeby niniejszego artykułu nie będę przytaczał procedury przystępowania nowych członków do istniejącego już EUWT, odsyłając Czytelników do art. 6a Rozporządzenia (WE) nr 1082/2006..., op. cit.

R. Kuligowski, Europejskie Ugrupowanie Współpracy Terytorialnej a współpraca zagraniczna jednostek samorządu terytorialnego, „Białostockie Studia Prawnicze” 2012, nr 12, s. 48-49.

Art. 5 ust. 1. Ustawy o europejskim ugrupowaniu..., op. cit. Warto w tym miejscu nadmienić, że niedawno dokonano również nowelizacji Ustawy z dnia 4 września 1997 r. o działach administracji rządowej, zob.: Ustawa z dnia 19 listopada 2015 r. o zmianie ustawy o działach administracji rządowej oraz niektórych innych ustaw (Dz.U. z 2015 r. poz. 1960).

Art. 4 ust. 1-3. Ustawy o europejskim ugrupowaniu..., op. cit. Por.: J. Zimmerman, Prawo..., op. cit., s. 186. 
nych może wystąpić do innego ministra (nie wymienionego wcześniej) o wyrażenie opinii w sprawie zgody na przystąpienie do ugrupowania lub zatwierdzenia jego konwencji, jeżeli jest to uzasadnione charakterem działań ugrupowania. Taki minister ma wtedy 14 dni na wyrażenie opinii, a niezajęcie przez niego stanowiska oznacza pozytywną opinię ${ }^{24}$.

Ważność uchwały podjętej przez jednostkę samorządu terytorialnego/decyzji innych podmiotów prawa publicznego jest zależna od wydania ww. zgody. Jest ona wydawana przez ministra właściwego ds. zagranicznych ${ }^{25}$. Zgodnie z art. 4 ust. 4. Rozporządzenia nr 1082/2006 o EUWT czas na wydanie zgody wynosi sześć miesięcy i ,jeżeli państwo członkowskie, które otrzymało powiadomienie, nie zgłosi sprzeciwu w tym terminie, uczestnictwo przyszłego członka oraz konwencję uważa się za zatwierdzone. Jednakże państwo członkowskie, w którym ma się znajdować proponowana siedziba statutowa EUWT, musi formalnie zatwierdzić konwencję, w celu umożliwienia utworzenia EUWT"26. Minister może odmówić wydania zgody, jeżeli:

- uczestnictwo danego podmiotu lub konwencja nie są zgodne z: Rozporządzeniem unijnym nr 1082/2006 o EUWT (z uwzględnieniem późniejszych zmian); innymi unijnymi przepisami dotyczącymi działań i działalności EUWT; przepisami krajowymi dotyczącymi uprawnień i kompetencji przyszłego członka;

- takie uczestnictwo nie jest uzasadnione ze względu na interes publiczny lub porządek publiczny danego państwa członkowskiego; lub

- statut nie jest zgodny z konwencją ${ }^{27}$.

Jest to katalog zamknięty przesłanek skutkujących uzasadnioną odmową wydania zgody i, w stosownych przypadkach (niestety nie wyszczególniono, w jakich), wskazaniem koniecznych zmian w konwencji. Wydanie powyższej decyzji zawiera również rozstrzygnięcie w zakresie zatwierdzenia konwencji EUWT ${ }^{28}$. Warto wskazać, że podjęcie uchwały przez Radę Ministrów w przedmiocie uczestnictwa Polski lub organu administracji rządowej w danym ugrupowaniu oznacza zatwierdzenie konwencji ${ }^{29}$.

Jeżeli siedziba statutowa ugrupowania znajduje się na terytorium Polski, kolejnym krokiem jest wpis do rejestru europejskich ugrupowań współpracy terytorialnej prowadzonego przez ministra właściwego do spraw zagranicznych skutkujący przy- 
znaniem danemu EUWT osobowości prawnej ${ }^{30}$. Rejestr ma charakter jawny i jest prowadzony przez ministerstwo w formie elektronicznej ${ }^{31}$. Wpis do rejestru następuje na wniosek złożony przez osobę upoważnioną do tego przez członków ugrupowania. Niezbędnymi elementami zgłoszenia są:

1) konwencja i statut ugrupowania;

2) uchwały albo decyzje członków ugrupowania o przyjęciu statutu;

3) upoważnienie przedstawiciela ugrupowania do dokonywania czynności związanych z wpisaniem ugrupowania do rejestru;

4) zgody na przystąpienie każdego z członków do ugrupowania wydane zgodnie $\mathrm{z}$ art. 4 ust. 3 rozporządzenia 1082/2006 32 .

Do dokumentów w języku obcym załącza się poświadczone tłumaczenie na język polski. W przypadku braków w zgłoszeniu, minister wzywa przedstawiciela ugrupowania do uzupełnienia braków w terminie 14 dni od otrzymania wezwania. Nieusunięcie wskazanych uchybień skutkuje odmową wpisu do rejestru ${ }^{33}$. Po rejestracji, ugrupowanie ma obowiązek przesłać w ciągu 10 dni informację o utworzeniu EUWT do Komitetu Regionów (zgodnie z określonym ściśle wzorem wniosku) w celu opublikowania we właściwym Dzienniku Urzędowym UE, natomiast członkowie ugrupowania informują państwa członkowskie, których to dotyczy, i Komitet Regionów o rejestracji lub publikacji konwencji i statutu ${ }^{34}$.

Nadzór nad każdym ugrupowaniem mającym siedzibę statutową w Polsce oraz nad podmiotami z Polski będącymi członkami EUWT mającym siedzibę statutową poza krajem sprawuje minister właściwy do spraw zagranicznych ${ }^{35}$.

Zasady rozwiązania EUWT muszą być określone w konwencji każdego ugrupowania, natomiast ogólne zasady likwidacji określa art. 14, a regulowanie zobowiązań EUWT art. 12 unijnego rozporządzenia 1082/2006 ${ }^{36}$. UE pozostawiła szczegóły likwidacji państwu członkowskiemu, na terenie którego znajduje się siedziba ugrupowania $^{37}$. Likwidacja następuje dobrowolnie w wyniku uchwały jego członków lub też odgórnie przez wykreślenie z rejestru wskutek naruszenia prawa (jeżeli ugrupo-

Art. 7 i 8 . Ustawy o europejskim ugrupowaniu..., op. cit. Por.: Ż. Szczegłowa, Europejskie Ugrupowanie Współpracy Terytorialnej we współpracy transgranicznej, (w:) Współpraca transgraniczna. Aspekty..., op. cit., s. 55.; R. Kuligowski, Europejskie Ugrupowanie..., op. cit., s. 50. Szerzej o przejawach zdolności prawnej: J. Boć, S. Malarski, Problemy prawne regionalizacji w Europie, Wrocław 2008, s. 84. Por.: M. Ofiarska, Współpraca gospodarcza i finansowa..., op. cit., s. 233. Art. 9 ust. 2. Ustawy o europejskim ugrupowaniu..., op. cit. Por.: R. Kuligowski, Europejskie Ugrupowanie..., op. cit., s. 50 .

33 Art. 9 ust. 3. Ustawy o europejskim ugrupowaniu..., op. cit.

34 Art. 5 Rozporządzenia (WE) nr 1082/2006..., op. cit.

35 Art. 20 i 21 ust. 1 i 2 . Ustawy o europejskim ugrupowaniu..., op. cit. Por.: J. Zimmermann, Prawo..., op. cit., s. 186; M. Ofiarska, Współpraca gospodarcza i finansowa..., op. cit., s. 231-233.

36 Por. M. Perkowski, Międzynarodowa współpraca..., op. cit., s. 117.

37 W Polsce szczegóły likwidacji są określone w art. 21 ust. 3 i 4, art. 21a ust. 2 oraz art. 22 ustawy o europejskim ugrupowaniu współpracy terytorialnej. Likwidację dopracowano w ostatniej nowelizacji ustawy. 
wanie lub jego członkowie nie zaprzestaną pomimo upomnień dalszego naruszania prawa). Przyczyny wykreślenia to:

- prowadzenie przez ugrupowanie działalności naruszającej przepisy danego państwa dotyczące porządku publicznego, bezpieczeństwa publicznego, zdrowia publicznego lub moralności publicznej lub naruszającą interes publiczny państwa członkowskiego;

- zaprzestanie spełniania wymogów ustanowionych we wspomnianym już wcześniej art. 1 ust. 2 lub art. 7 (tu głównie chodzi o prowadzenie określonych działań związanych ze współpracą terytorialną między członkami danego ugrupowania, a szczególnie zadań dotyczących realizacji programów współpracy lub ich części, lub też realizacji operacji wspieranych przez Unię za pośrednictwem Europejskiego Funduszu Rozwoju Regionalnego, Europejskiego Funduszu Społecznego, lub Funduszu Spójności) lub działalność poza zakresem powierzonych zadań określonych w art. 7 (szczególnie ust. 4: „Zadania powierzone EUWT przez jego członków nie mogą dotyczyć wykonywania uprawnień przyznanych na mocy prawa publicznego lub obowiązków, których celem jest ochrona ogólnych interesów państwa lub ochrona ogólnych interesów innych organów publicznych, takich jak uprawnienia policyjne i regulacyjne, wymiar sprawiedliwości i polityka zagraniczna") ${ }^{38}$.

Przesłanki skutkujące wykreśleniem z rejestru są określone ogólnie - szczególnie te wynikające $\mathrm{z}$ art. 13 rozporządzenia nr 1082/2006 o EUWT (np.: naruszenie przepisów o moralności publicznej) - biorąc pod uwagę to, jak poważnym podmiotem jest w swej istocie EUWT. Ponadto należy wskazać również upływ czasu, na jaki ugrupowanie zostało utworzone, jako przesłankę likwidacji ugrupowania (EUWT może zostać powołane na czas określony lub nieokreślony) ${ }^{39}$.

Warto zwrócić uwagę na wprowadzenie do ustawy o EUWT instytucji milczącej zgody organu administracji publicznej ${ }^{40}$. Instytucja ta może wydłużyć procedurę zakładania ugrupowań i trudno znaleźć argumenty, którymi można poprzeć wprowadzone rozwiązanie. Tym bardziej jest to trudne, że jeszcze w trakcie prac nad stworzeniem ostatecznej koncepcji ugrupowań polski rząd uzależnił poparcie dla projektu unijnego rozporządzenia o EUWT od wykreślenia przepisu w brzmieniu ,jeżeli żadna decyzja nie zostanie przekazana w tym terminie, EUWT uważa się za zatwierdzone", bądź takiego jego przeredagowania, aby zgoda państwa członkowskiego była warunkiem sine qua non powstania ugrupowania ${ }^{41}$. Zastanawiające jest

Art. 12. Ustawy o europejskim ugrupowaniu współpra
i 7. Rozporządzenia (WE) nr 1082/2006..., op. cit.

Por.: A. Piotrowska, Europejskie Ugrupowanie..., op. cit., s. 203.

Zob.: art. 6 ust. 2-4 Ustawy o europejskim ugrupowaniu..., op. cit.

Warto wskazać, że negatywna opinia Rządu RP z 2006 r. w punkcie dotyczącym wprowadzenia instytucji milczącej zgody do unijnego rozporządzenia nr 1082/2006 została podtrzymana również w opinii z 2012 r. dotyczącej rozporządzenia nr 1032/2013. Zob.: Informacja dla Sejmu i Senatu o udziale Rzeczypospolitej Polskiej 
to, na ile instytucja milczącej zgody ułatwia życie założycielom ugrupowań, a na ile administracji publicznej. Zgoda państwa powinna być wyrażona w sposób jednoznaczny, a nie dorozumiany. Wydaje się, że mnogość aktów prawnych i obowiązków administracji publicznej przybrała rozmiar tak ogromny, że milcząca zgoda stanie się normą w polskim porządku prawnym. Od ułatwienia życia obywatelowi do bezczynności administracji jest bardzo niedaleka droga. Warto wskazać, że „opieszałość administracji, a nierzadko wręcz jej bierność, wskazywana jest jako podstawowa nieprawidłowość w funkcjonowaniu administracji publicznej w Polsce"42.

Proces zakładania EUWT jest skomplikowany (biorąc pod uwagę konieczność pogodzenia interesów poszczególnych członków ugrupowania, sprecyzowanie wizji działalności takiego ugrupowania oraz konieczność zadośćuczynienia wymogom formalnym) oraz czasochłonny. Obecnie istnieje 61 EUWT, w tym 4 w Polsce ${ }^{43}-$ są to: Europejskie Ugrupowanie Współpracy Terytorialnej TRITIA z ograniczoną odpowiedzialnością z siedzibą w Cieszynie ${ }^{44}$, EUWT TATRY z ograniczoną odpowiedzialnością z siedzibą w Nowym Targu ${ }^{45}$, Środkowoeuropejski Korytarz Transportowy Europejskie Ugrupowanie Współpracy Terytorialnej z ograniczoną odpowiedzialnością z siedzibą w Szczecinie ${ }^{46}$ oraz EUWT NOVUM z ograniczoną odpowiedzialnością z siedzibą w Jeleniej Górze. Formalnie w Unii Europejskiej trwają prace nad uruchomieniem 12 kolejnych ugrupowań ${ }^{47}$, choć z perspektywy Polski Wschodniej należałoby jeszcze doliczyć dwa, nad których utworzeniem pracuje Województwo Podlaskie - Europejskiego Ugrupowania Współpracy Terytorialnej „Polska Wschodnia” i Europejskiego Ugrupowania Współpracy Terytorialnej „Puszcza Białowieska” - oraz jedno opracowywane przez Euroregion „Niemen”.

w pracach Unii Europejskiej w okresie lipiec-grudzień 2005 r. (podczas Prezydencji brytyjskiej), Warszawa 2006, s. 41; Stanowisko Rządu RP dot. wniosku rozporządzenia Parlamentu Europejskiego i Rady zmieniającego rozporządzenie (WE) nr 1082/2006 Parlamentu Europejskiego i Rady z dnia 5 lipca 2006 r. w sprawie europejskiego ugrupowania współpracy terytorialnej (EUWT) w celu doprecyzowania, uproszczenia i usprawnienia procesu tworzenia takich ugrupowań oraz ich funkcjonowania przyjęte w dniu 19 stycznia 2012 r.

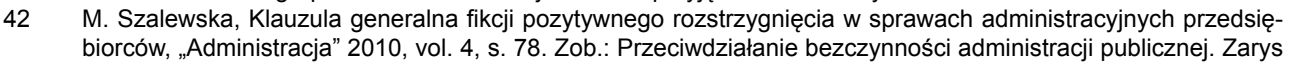
problematyki, R. Suwaj i M. Perkowski (red.), Białystok 2010.

43 Wykaz europejskich ugrupowań współpracy terytorialnej (EUWT), których utworzenie zgłoszono Komitetowi Regionów Unii Europejskie zgodnie z art. 5 rozporządzenia (WE) nr 1082/2006 Parlamentu Europejskiego i Rady, Bruksela, COR-2013-04606-00-12-ADMIN-TRA (EN), tryb dostępu: https://webapi.cor.europa.eu/documentsanonymous/cor-2013-04606-00-12-admin-tra-pl.docx (data dostępu: 26.05.2016 r.). Por.: Rejestr EUWT, których siedziba statutowa znajduje się na terytorium RP, prowadzony przez Ministra Spraw Zagranicznych, tryb dostępu: https://www.msz.gov.pl/resource/ae9ef1e2-e263-4631-a42f-be53ab7f6f95:JCR (data dostępu: 26.05.2016 r.).

44 Oficjalna strona EUWT TRITIA, tryb dostępu: http://www.egtctritia.eu/pl/ (data dostępu: 26.11.2015 r.).

45 Oficjalna strona EUWT TATRY, tryb dostępu: http://www.euwt-tatry.eu/ (data dostępu: 26.11.2015 r.).

46 Oficjalna strona ŚKT EUWT, tryb dostępu: http://www.cetc-egtc.eu/ (data dostępu: 26.11.2015 r.).

47 Oficjalna strona Komitetu Regionów, tryb dostępu: https://portal.cor.europa.eu/egtc/CoRActivities/Pages/egtc -under-construction.aspx (data dostępu: 26.11.2015 r.). 


\section{Wpływ władzy wykonawczej na działalność EUWT z polskiej perspektywy}

W dobie wzrostu samodzielności europejskich regionów, ważną rolę odgrywają relacje między władzami państwowymi i władzami regionalnymi. Stopień samodzielności regionów jest różny, zależny od charakteru państw ${ }^{48}$. Warto przytoczyć przepisy Europejskiej Karty Samorządu Regionalnego, która - choć nie jest dokumentem wiążącym - jest istotna z punktu widzenia rozwoju współpracy międzynarodowej samorządu terytorialnego. Postuluje się w niej m.in. uznanie w konstytucji w możliwie najszerszym zakresie zasady samorządności regionalnej ${ }^{49}$. W tym samym dokumencie stwierdza się, że „w dziedzinach objętych ich kompetencjami regiony powinny być upoważnione do podejmowania współpracy międzyregionalnej lub transgranicznej zgodnie z procedurami nałożonymi przez prawo wewnętrzne. Współpraca ta powinna być prowadzona zgodnie z prawem wewnętrznym i międzynarodowymi zobowiązaniami państwa" ${ }^{50}$. W przypadku EUWT te postulaty są spełnione - stosowne podstawy prawne prowadzenia współpracy przez jednostki samorządu terytorialnego w ramach tej formuły istnieją i są stosowane, choć z polskiej perspektywy nie jest to instrument popularny, o czym świadczy niewielka liczba utworzonych ugrupowań i niewielka efektywność prowadzonych przez nie działań, które w zasadzie nie różnią się od tego, co dotąd robiono w ramach euroregionów czy zwykłych umów o współpracy bilateralnej.

Z perspektywy Polski, śledząc kolejne etapy zakładania ugrupowań rzuca się w oczy udział władzy wykonawczej w znacznej części tego procesu. Pierwszym najbardziej wyrazistym przykładem (z przyczyn zupełnie oczywistych) jest podjęcie uchwały przez Radę Ministrów o udziale Polski lub organu administracji rządowej w EUWT. Jest to element jak najbardziej uzasadniony - tym bardziej, że wiąże się z nim wiele obszarów problematycznych (np.: kwestia pozyskiwania środków i realizacja projektów przez ugrupowanie z udziałem władz publicznych a zasady związane z konkurencją, w tym z zakazem uprzywilejowanego traktowania podmiotów w dostępie do środków publicznych). Idąc dalej - jednostki samorządu terytorialnego, podmiotu prawa publicznego, przedsiębiorstwa publicznego albo przedsiębiorstwa muszą uzyskać zgodę na udział w ugrupowaniu od ministra właściwego ds. zagranicznych (uzgodnioną z innymi ministrami) ${ }^{51}$. Ponadto wszyscy członko-

\footnotetext{
48 W państwach unitarnych samodzielność regionów jest generalnie mniejsza niż w państwach federalnych. Por.: B. Banaszak, Prawo konstytucyjne, Warszawa 1999, s. 588 i n., K. Wlaźlak, Rozwój regionalny jako zadanie administracji publicznej, Warszawa 2010, s. 30.

49 Art. 2 ust. 1. Europejskiej Karty Samorządu Regionalnego, przyjęta przez IV sesję Kongresu Władz Lokalnych i Regionalnych, która odbyła się 3-5 czerwca 1997 r. w Strasburgu (ETS No. 122). Zob.: L. Kieres, Europejska Karta Samorządu Regionalnego, (w:) P. Buczkowski, K. Bondyra, P. Śliwa (red.), Jaka Europa? Regionalizacja a integracja, Poznań 1998, s. 81 in.

$50 \quad$ Ibidem, art. 8 ust. 1.

51 Zob.: Art. 4 ust. 1-3, art. 6 ust. 1, Ustawy o europejskim ugrupowaniu..., op. cit. Por.: J. Zimmerman, Prawo..., op. cit., s. 186.
} 
wie EUWT mającego siedzibę statutową poza Polską, którzy działają na podstawie prawa polskiego, muszą informować ministra właściwego ds. zagranicznych po pierwsze o nabyciu przez to ugrupowanie osobowości prawnej, przekazując jego konwencję i statut, a po drugie o zmianie konwencji lub statutu ugrupowania. Gdy jest zmieniana konwencja lub statut ugrupowania z siedzibą statutową w innym kraju, a jego członkiem jest Polska lub organ administracji rządowej, to zgodę na zmiany wyraża w drodze uchwały Rada Ministrów. Jeżeli członkami są jednostki samorządu terytorialnego, podmiotu prawa publicznego, przedsiębiorstwa publicznego lub przedsiębiorstwa, to taką zgodę wyraża minister właściwy ds. zagranicznych (w uzgodnieniu z innymi ministrami) ${ }^{52}$. Rejestr ugrupowań z siedzibą statutową na terytorium Polski, a także wszelkie zmiany w rejestrze są w kompetencji tego samego ministra - podobnie jest z nadzorem nad EUWT lub jego członkami działającymi na podstawie prawa polskiego. Minister właściwy do spraw zagranicznych również ma w swoich kompetencjach m.in. wezwanie ugrupowania do zaniechania naruszeń prawa i podjęcia działań skutkujących zaprzestaniem prowadzenia działalności z nim sprzecznej, ma prawo do cofnięcia zgody na udział podmiotów działających na podstawie prawa polskiego w EUWT, a także do wykreślenia ugrupowania z rejestru i wyznaczenia jego likwidatora ${ }^{53}$ (oczywiście z zachowaniem wszystkich przepisów przewidzianych przez ustawę o EUWT i unijne rozporządzenia).

Analizując powyższe można stwierdzić, że w Polsce na etapie zakładania, działalności oraz likwidacji EUWT jest konstrukcją w dużej mierze zależną od władzy wykonawczej, szczególnie, jeżeli członkiem ugrupowania są organy władzy wykonawczej lub Rzeczpospolita Polska. Ponadto można mieć obawy, że może dojść do sytuacji, w której władza wykonawcza będzie nadzorowała działalność... władzy wykonawczej, jeśli dany jej organ będzie członkiem ugrupowania. Wydaje się, że jest to sprzeczne z zasadą Nemo iudex in causa sua, więc może rzutować na bezstronność organu rozstrzygającego sprawę. Jest to jednak aspekt wymagający dalszych, pogłębionych badań.

\section{Podsumowanie}

Europejskie Ugrupowanie Współpracy Terytorialnej jest formułą, która w założeniu ma pomóc rozwijać regiony i umacniać ich rolę na arenie międzynarodowej. Ugrupowania stanowią nową jakość współpracy, ale działaniami - póki co - nie odróżniają się od euroregionów. Unia Europejska zamiast udoskonalić formułę euroregionów, zdecydowała się na stworzenie całkiem nowego narzędzia. Niestety - sam proces zakładania ugrupowań (w tym czasochłonność procedur) nie sprzyja rozwija-

\footnotetext{
52 Zob.: Ibidem, 9a ust. 2-4, art. 12 ust. 1 oraz art. 15. Por.: J. Zimmerman, Prawo..., op. cit., s. 186; M. Ofiarska, Współpraca gospodarcza i finansowa..., op. cit., s. 232-233.

53 Zob.: Ibidem, art. 20-22. Por.: M. Ofiarska, Współpraca gospodarcza i finansowa..., op. cit., s. 233.
} 
niu tej nowej formy współpracy. Polski ustawodawca również sprawy w tym zakresie nie ułatwił, wprowadzając instytucję milczącej zgody do ustawy o EUWT, która zamiast przyspieszać procedurę, może ją przedłużyć. W przypadku instytucji EUWT z perspektywy Polski daje się zauważyć duży wpływ władzy wykonawczej na ugrupowania - przynajmniej w ujęciu ustawowym. Jednak to dopiero praktyka działalności EUWT pokaże, czy jest to wpływ dobry i potrzebny.

\section{BIBLIOGRAFIA}

Banaszak Bogusław. 1999. Prawo konstytucyjne. Warszawa: Wydawnictwo C.H. Beck.

Bandarzewski Kazimierz et al. Ustawa o samorządzie gminnym. Komentarz. LexPolonica nr 8175265.

Boć Jan, Malarski Stanisław. 2008. Problemy prawne regionalizacji w Europie. Wrocław: Kolonia Limited.

Cucu Anca-Adriana. 2011. „Enhancing the Performance of Cross Border Cooperation Governance through Legal Community Instruments: the Case of the European Group of Territorial Co". Eurolimes (3): 201-212.

Dołzbłasz Sylwia, Raczyk Andrzej. 2010. Współpraca transgraniczna w Polsce po akcesji do UE. Warszawa: Oficyna Wolters Kluwer business.

Kieres Leon. 1998. Europejska Karta Samorządu Regionalnego. W: Piotr Buczkowski, Krzysztof Bondyra, Piotr Śliwa (red.), Jaka Europa? Regionalizacja a integracja, 79-93. Poznań: Wydawnictwo Wyższej Szkoły Bankowej.

Kment Martin. 2012. „Der Europäische Verbund für territoriale Zusammenarbeit”. Die Verwaltung (45): $155-169$.

Kosikowski Cezary, Joanna M. Salachna (red.). 2012. Finanse samorządowe - 580 pytań i odpowiedzi: wzory uchwał, deklaracji, decyzji, umów. Warszawa: Wolters Kluwer SA.

Kuligowski Rafał. 2012. „Europejskie Ugrupowanie Współpracy Terytorialnej a współpraca zagraniczna jednostek samorządu terytorialnego". Białostockie Studia Prawnicze (12): 45-56.

Mik Cezary. 2006. „Status władz regionalnych i lokalnych państw członkowskich Unii Europejskiej w świetle prawa wspólnotowego". Ruch Prawniczy, Ekonomiczny i Socjologiczny 68 (2): 221-252.

Nadalutti Elisabetta. 2013. „Does the 'European Grouping of Territorial Co-operation'Promote Multi-level Governance within the European Union?". Journal of Common Market Studies 51 (4): 756-771.

Ofiarska Małgorzata. 2012. Współpraca gospodarcza i finansowa j.s.t. z organami lokalnymi państw sąsiednich. W: Cezary Kosikowski, Joanna M. Salachna (red.), Finanse samorządowe - 580 pytań i odpowiedzi: wzory uchwał, deklaracji, decyzji, umów, 222-246. Warszawa: Wolters Kluwer SA.

Pechstein Matthias, Michał Deja. 2011. „Was ist und wie funktioniert ein EVTZ?”, Europarecht (46): 357-383.

Perkowski Maciej (red.). 2010. Współpraca transgraniczna. Aspekty prawno-ekonomiczne. Białystok: Wydawnictwo Prawo i Partnerstwo. 
Piotrowska Aldona. 2011. „Europejskie Ugrupowanie Współpracy Terytorialnej - nowy podmiot administrujący”. Zeszyty Naukowe Uniwersytetu Ekonomicznego w Krakowie (870): 187-205.

Skorupska Adriana, Michał Wojnarowicz. 2015. „Międzynarodowe sieci samorządowe jako skuteczne narzędzie wpływu". Biuletyn PISM 34 (1271): 1-2.

Solarz Piotr. 2009. Współpraca transgraniczna jako czynnik procesu integracji europejskiej. Warszawa: VIZJA.

Supernat Jerzy. 2005. Europejska przestrzeń administracyjna (zagadnienia wybrane). W: Zbigniew Janku, Zbigniew Leoński, Marek Szewczyk, Michał Waligórski, Krystyna Wojtczak (red.), Europeizacja polskiego prawa administracyjnego, 78-86. Wrocław: Kolonia Limited.

Suwaj Robert, Maciej Perkowski (red.). 2010. Przeciwdziałanie bezczynności administracji publicznej. Zarys problematyki. Białystok: Temida2.

Szalewska Małgorzata. 2010. „Klauzula generalna fikcji pozytywnego rozstrzygnięcia w sprawach administracyjnych przedsiębiorców". Administracja (4): 71-99.

Szczegłowa Żenia. 2010. Europejskie Ugrupowanie Współpracy Terytorialnej we współpracy transgranicznej. W: Maciej Perkowski (red.), Współpraca transgraniczna. Aspekty prawno-ekonomiczne, 50-61. Białystok: Wydawnictwo Prawo i Partnerstwo.

Varró Krisztina. 2014. „Spatial governance in the Dutch-German-Belgian borderlands”. International Journal of Urban and Regional Research 38 (6): 2235-2255.

Wlaźlak Katarzyna. 2010. Rozwój regionalny jako zadanie administracji publicznej. Warszawa: Wolters Kluwer SA.

Zimmermann Jan. 2014. Prawo administracyjne. Warszawa: Wolters Kluwer Polska. 


\section{THE COMPETENCE OF THE EXECUTIVE POWER WITH REGARD TO THE EUROPEAN GROUPING OF TERRITORIAL COOPERATION FROM POLAND'S PERSPECTIVE}

Cross-border cooperation may be based on specialized organizational structures. One such is the European Grouping of Territorial Cooperation (EGTC). The catalogue of entities entitled to create a Grouping is diverse and the registration procedures are mainly based on the law of the European Union Member State, where the particular Grouping's headquarters are to be located. The Polish legislation on this issue is still being formed, but the tendency to strengthen the influence of the central executive power on the Groupings'establishment, operating and decommissioning processes, is already visible. However, only development (or lack of it, or even a regress) of cross-border cooperation based on the formula of the EGTC will show whether the national legislative solutions will support the operation of Groupings from Poland's perspective.

Keywords: EGTC, executive power, cross-border cooperation, international cooperation of regions, tacit approval

Słowa kluczowe: EUWT, władza wykonawcza, współpraca transgraniczna, międzynarodowa współpraca regionów, milcząca zgoda 